\title{
„KI SZÉP, KI JÓ?”* \\ AZ ATTRAKTIVITÁS HATÁSA A HARMADIK SZEMÉLYÜ BÜNTETÉSRE, JUTALMAZÁSRA**
}

\author{
PUTZ ÁDÁM - PALOTAI RÓBERT - BERECZKEI TAMÁS
}

PTE BTK Pszichológia Intézet

E-mail: putz.adam@pte.hu

Beérkezett: 2014. október 10. - Elfogadva: 2014. december 20.

\begin{abstract}
Kutatásunkban egy általunk kifejlesztett kisérleti játékprogram, a harmadik személyü büntetöjutalmazó játék (Third-party Punishment and Reward Game, TPRG) segítségével vizsgáltuk az attraktivitás normafenntartó viselkedésre gyakorolt hatását. Korábbi vizsgálatok alátámasztják, hogy az észlelt vonzerö szoros kapcsolatban áll a megbízhatósági itéletekkel: az attraktívabb embereket megbizhatóbbaknak tartják a kísérleti személyek (MULFORD, ORBELL, SHATTO és STOCKARD, 1998). A vonzó külsejü személyekkel szemben ugyanakkor magasabb elvárásokat is támasztunk. Amennyiben nem szolgálnak rá a beléjük vetett bizalomra, a vonzóként jellemzett csalók szigorúbb büntetésekre számíthatnak (WILSON és ECKEL, 2006). Vizsgálatunkban sztereotípia-konzisztens (attraktív együttmüködö és nem attraktív csaló), valamint sztereotípia-inkonzisztens (attraktív csaló és nem attraktív együttmüködö) helyzeteket alakítottunk ki, továbbá felmértük, hogy az egyes játékosok milyen érzelmeket váltottak ki a vizsgálati személyekből (düh, elégedettség). A vizsgálatban a Pécsi Tudományegyetem 115 hallgatója (58 nö és 57 férfi) vett részt, életkoruk szerint 18 és 31 év közöttiek (átlag $=21,2 ; S D=2,12$ ). Eredményeink alapján megállapitható, hogy a sztereotípia-inkonzisztens helyzetekben a kísérleti személyek intenzívebb érzelmeket éltek át, mely magasabb büntetések és jutalmazások kiszabásához vezetett. Ennek legvalószínübb magyarázata a vonzó személyekkel szembeni magasabb elvárásokban keresendö.
\end{abstract}

Kulcsszavak: normafenntartás, harmadik személyü büntetés-jutalmazás, erös reciprocitás, attraktivitás, szépségsztereotípiák, sztereotípia-konzisztencia/inkonzisztencia, TPRG

\footnotetext{
* Móricz Zsigmond (1909) Hét krajcár c. novelláskötet.

** A kutatást az Országos Tudományos Kutatási Alapprogramok - OTKA (K-101762) támogatta.
} 


\section{ELMÉLETI HÁTTÉR}

Együttmüködés és versengés

Az evolúciós pszichológia egyik legnehezebb feladata az emberek közötti együttműködés és versengés egyidejü magyarázata. DARWIN (1859,61-62) híres tételének fényében, mely szerint a túlélésért folytatott küzdelemben kizárólag a legrátermettebb egyedek maradhatnak talpon, sokáig érthetetlen jelenségnek tűnt az emberi közösségekben széleskörűen felfedezhető önzetlenség (FEHR és FISCHBACHER, 2003).

A dilemma feloldását a TRIVERS (1971) által ismertetett reciprok altruizmus jelensége kínálta, amely szerint az együttműködésből származó előnyök - a kölcsönösség révén - hosszabb távon felülmúlják az önző viselkedés nyújtotta átmeneti nyereséget. Az esetek többségében ezek a tranzakciók meglehetősen aszimmetrikusan alakulnak, s végeredményképpen mindkét felet nagyobb előnyökhöz juttatják, mint amekkora költséggel az önzetlen cselekedet eredetileg járt. A reciprok altruizmus múködésének elengedhetetlen feltétele a másokba vetett bizalom, a kooperációs készség megléte. Japán kutatók kísérletileg igazolták, hogy szociális kapcsolataink során hajlamosak vagyunk a „társas csere heurisztikáját” követni, mely arra ösztönöz minket, hogy megbízzunk másokban és együttműködjünk akár számunkra ismeretlen személyekkel is (BERECZKEI, 2009; KIYONARI, TANIDA és YAMAGISHI, 2000).

Az emberi csoporton belüli társas cserekapcsolatok stabilizálását általánosan elfogadott szabályok, normák segítik (FEHR és FISCHBACHER, 2004a). A normakövetés képessége lehetővé teszi az egyének közötti konfliktusok minimalizálását, valamint a potyalesők megbüntetése révén az együttműködés elterjedését és fenntartását (BERECZKEI, 2009, 135). Ezeknek a normáknak a betartása az ún. erös reciprocitással magyarázható, amely szerint az emberek alapvetően készek együttmúködni másokkal, s akár saját költségükön is hajlandóak megbüntetni a normaszegő csalókat, illetve megjutalmazni a normát túlteljesítőket (GINTIS, BOWLES, BOYD és FEHR, 2003).

Az erős reciprocitás vizsgálatára fejlesztették ki a harmadik személyü büntető játékot (Third-party Punishment Game, TPG), melyben két játékos fogolydilemma, bizalom vagy ultimátum játékot játszik, amit egy harmadik résztvevő figyelemmel kísér (FEHR és FiSCHBACHER, 2004b). A játék végén a megfigyelőnek saját számlája terhére lehetősége nyílik egyik vagy akár mindkét játékos megbüntetésére. Számos vizsgálatban bebizonyosodott, hogy a résztvevők rendkívül érzékenyen reagálnak az együttműködés, illetve az igazságos elosztás normájának megsértésére. A kísérleti személyek saját költségükön is hajlandóak voltak megbüntetni a csaló, illetve megjutalmazni az együttműködő játékosokat; függetlenül attól, hogy a beavatkozás költségeinek megtérülésére sem akkor, sem a jövőben nem számíthattak. A kutatók szerint a beavatkozásokat a csalókkal szembeni erös negatív érzelmek motiválták (BERECZKEI, 2009; FEHR és FISCHBACHER, 2004b; GINTIS, BOWLES, BOYD és FEHR, 2003). 


\section{Normafenntartó érzelmek}

A természetben a normafenntartó viselkedés - nyilvánvaló költségei ellenére számos közvetlen és közvetett haszonnal járhatott. Ilyenek például a közösségen belüli jó hírnév szerzése, az együttműködő személyek figyelmének felkeltése, a csalók elrettentése. Mások altruista büntetése és jutalmazása evolúciós értelemben költséges jelzésnek minősül, mely az egyén rátermettségéről és erőforrásokban való bővelkedéséről árulkodik (WEST, MOUDEN és GARDNER, 2011).

A fentebb említett kísérleti játékokban a résztvevők annak ellenére büntették a csalókat és jutalmazták az együttműködőket, hogy a kutatók kizárták mind a hírnévszerzés, mind a reciprocitás lehetőségét (a játékosok mindössze egyszer találkoztak). A kísérleti személyek tehát nem racionális megfontolások mentén, hanem érzelmeikre hallgatva hozták meg döntésüket. Az is kiderült, hogy az átélt düh intenzitása a csalás mértékétől függött. Minél szembetűnőbb volt a normasértés, annál intenzívebb dühöt éltek át a kísérleti személyek, s annál szigorúbb büntetéseket osztottak ki. Ezzel párhuzamosan minél erősebb pozitív érzelmet éltek át a kísérleti személyek, annál nagyobb jutalomban részesítették az együttműködőket (BERECZKEI, 2009; DE KWAADSTENIET, RIJKHOFF, VAN DIJK, 2013).

Látható, hogy társas kapcsolatainkban gyakran nem az előnyös költség/nyereség mérleg, hanem partnerünk iránti pozitív érzelmeink sarkallnak minket együttműködésre. Hasonlóképpen, a csalók büntetését vagy kiközösítését - a morális agressziót - a normaszegők által keltett düh motiválja (TRIVERS, 1971).

\section{Attraktivitás}

Az evolúciós pszichológia másik nagy érdeklődésre számot tartó területe a szépségkutatás. A szépség kultusza feltehetőleg egyidős magával az emberiséggel. Látszólag jelentős különbségek vannak az egyes emberek között a tekintetben, hogy kit tartanak vonzónak, kutatóknak mégis sikerült olyan univerzális sajátosságokat találniuk az emberi arcon, melyeket kortól és kultúrától függetlenül mindenhol előnyben részesítenek (GRAMMER, FINK, MøLLER, THORNHILL, 2003).

E szerint a megítélők vonzóbbnak tartják a populáció átlagához hasonló, szimmetrikus arcokat; a fiatal és egészséges arcbőrrel rendelkező, hosszú hajú nőket, valamint a maszkulin vonású férfiakat. ${ }^{1}$ A kutatók szerint azért preferáljuk a fenti vonásokat, mert azok viselőjük fiatalságát, fertilitását, valamint kórokozókkal szembeni ellenálló képességét, más szóval jó génjeit reklámozzák. Ezen tulajdonságok előnyben részesítése az utódok egészségi állapotának növelésén keresztül adaptív előnyhöz juttatta őseinket (BERECZKEI, 2010; GRAMMER, FINK, MøLLER és ThORNHill, 2003; LiTTLE, JONES és DeBRUine, 2011).

Szociálpszichológusok megfigyelték, hogy a fizikailag vonzó külsejü személyek megítélésekor erősen befolyásol minket az „aki szép, az jó is” sztereotípia (DION,

\footnotetext{
${ }^{1}$ Az attraktivitás ítéleteket befolyásoló egyéni, illetve környezeti változókról bővebben LITTLE, JONES és DEBRUINE (2011) cikkében olvashat.
} 


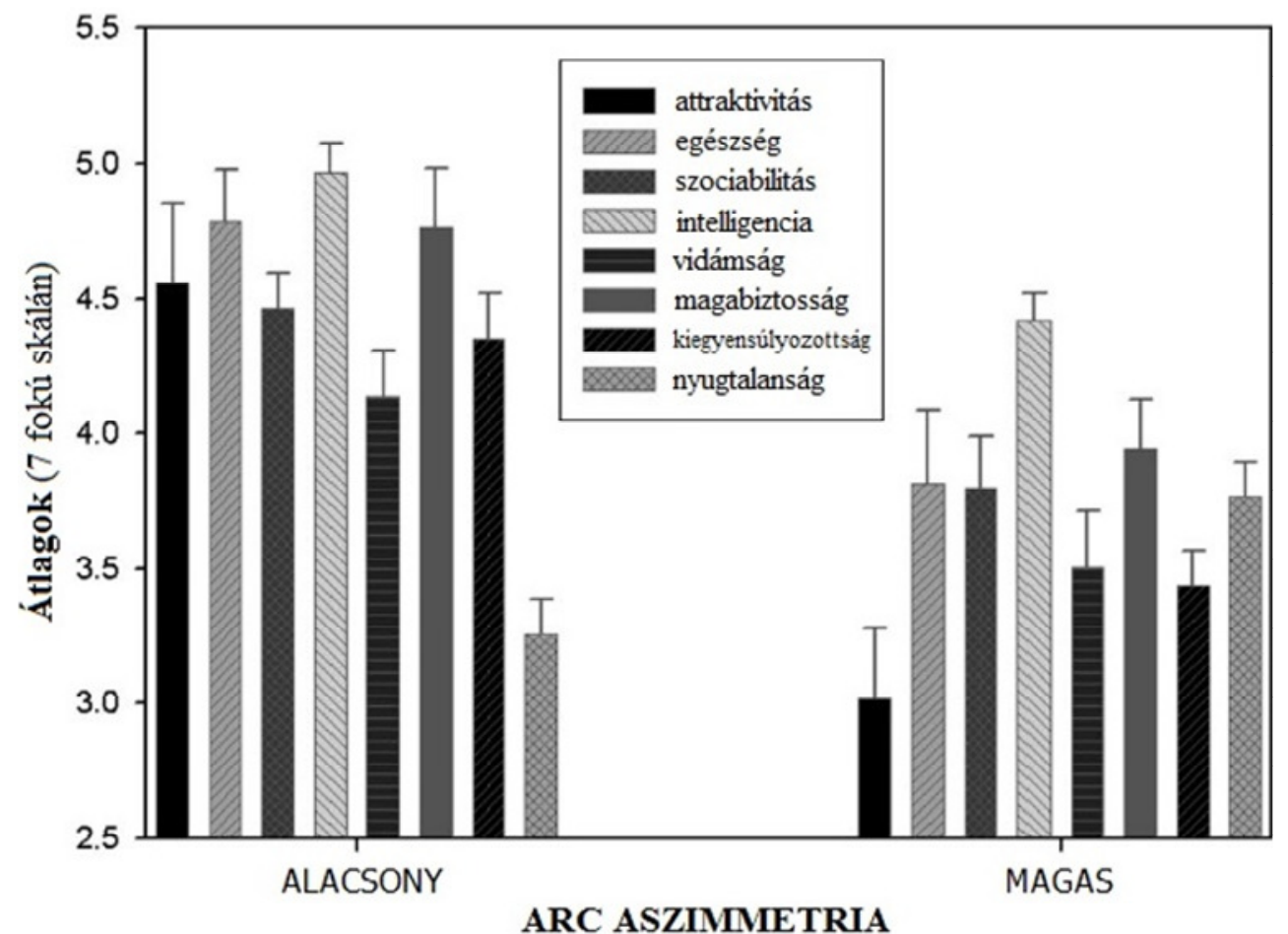

1. ábra. Az alacsony aszimmetriával rendelkező (vonzó), valamint a magas aszimmetriával rendelkező (kevésbé vonzó) női arcok értékelése különböző személyiségjegyek mentén (Forrás: Fink, NeAVE, MANNing és GRAMmer, 2006)

Berscheid és Walster, 1972). Fink, Neave, Manning és Grammer (2006) vizsgálatában felnőtt kísérleti személyek a szimmetrikusabb arcú nőket vonzóbbnak, egészségesebbnek, intelligensebbnek, sőt kiegyensúlyozottabbnak tartották, mint a kevésbé vonzó nőket (1. ábra). Ezzel párhuzamosan GRIFFIN és LANGLOIS (2006) kutatásában az „aki csúnya, az rossz is” sztereotípia működésére derült fény: a résztvevők az attraktívabb arcokhoz képest kevésbé szociábilisnak, altruistának és intelligensnek tartották a nem attraktív arcokat.

\section{Az attraktivitás szerepe a társas cserekapcsolatokban, nemi különbségek}

Társas cserekapcsolatainkban a vonzóbb külsejű embereket együttműködőbbnek gondoljuk másoknál és jobban megbízunk bennük (ANDREONI és PETRIE, 2008). Kísérleti játékok eredményeiből kiderült, hogy szociális dilemma helyzetben a résztvevők nagyobb valószínűséggel működnek együtt, illetve kezdő játékosként több pénzt utalnak át vonzó külsejü játékostársaiknak, mint a kevésbé attraktív 
személyeknek (Mulford, Orbell, ShatTo és STOCKard, 1998). Ez az ún. „szépségbónusz" azonban nem jelenti azt, hogy minden esetben a vonzóbb játékosok kerülnek ki győztesen a játék végén. Ha az attraktív játékos nem szolgál rá a belévetett bizalomra - nem vagy csak kis mértékben múködik együtt -, akkor sokkal szigorúbb büntetésre számíthat, mint egy kevésbé attraktív potyaleső (MULFORD, ORBELL, SHATTO és STOCKARD, 1998; WILSON és ECKEL, 2006).

\section{A társas sztereotípiák hatása az információfeldolgozásra}

A szociálpszichológiában Gordon Allport már az 1940-es években dokumentálta a társas elő́téletek emlékezetre gyakorolt hatását: vizsgálati személyei tévesen, sztereotípia-konzisztens módon idézték fel a hallott történetet (PAYNE, JACOBY és LAMBERT, 2004). Ez az eredmény a kognitív séma modellel magyarázható, mely szerint az információfeldolgozás során egymással erős asszociációs kapcsolatba kerülő elemek később könnyebben felidézhetők (THORNDYKE és HAYES-ROTH, 1979). Az ezt követő évtizedekben ugyanakkor számos ellentmondó eredmény is született, melyek a sztereotípia-inkonzisztens információk jobb felidézhetőségét hirdették (STANGOR és RUBLE, 1989). Ezek magyarázatára leggyakrabban az új, inkongruens információ, valamint a már meglévő tudás összeegyeztetésekor keletkező kognitív feszültséget jelölik meg a kutatók, mely mélyebb emlékezeti nyom kialakulását eredményezheti (HEIDER és mtsai, 2007). DIJKSTERHUIS és VAN KNIPPENBERG (1995) vizsgálatából kiderült, hogy a meglepő, inkongruens információkra való emlékezeti teljesítmény romlik, ha a kísérleti személyeket bonyolult, kognitív szempontból megterhelő feladat elé állítják.

A szépségsztereotípiákból kiindulva a szociális dilemma helyzetekben részt vevő játékosok viselkedését tehát két csoportra oszthatjuk: sztereotípia-konzisztensre, illetve sztereotípia-inkonzisztensre. Előbbi csoportba tartoznak az attraktív együttműködők, valamint a nem attraktív csalók, míg utóbbiba a nem attraktív együttműködők, továbbá az attraktív csalók. A korábban említett kísérletek közös jellemzője, hogy a fizikai vonzerő hatását a cserekapcsolatban közvetlenül érintett személyek reakcióin mérték le. Kutatásunk célja, hogy megvizsgáljuk az attraktivitás normafenntartó viselkedést befolyásoló szerepét egy kísérleti játékprogram, a harmadik személyü büntetó-jutalmazó játék (Third-party Punishment and Reward Game, TPRG) segítségével. Az általunk kifejlesztett játékprogram hiánypótló, hiszen egyszerre teszi lehetővé az erős reciprocitás mindkét oldalának - az altruista büntetésnek és jutalmazásnak - a vizsgálatát. Bár született már olyan vizsgálat, melyben mind a harmadik személyủ büntetést, mind a jutalmazást górcső alá vették, a független változó ott a környezeti feltételek bejósolhatósága volt, nem a játékosok attraktivitása (DE KWAADSTENIET, RIJKHOFF és VAN DIJK, 2013). 


\section{HIPOTÉZISEK}

\section{Első hipotézis}

Feltételezzük, hogy a vonzó személyekkel szembeni magasabb elvárások miatt a résztvevők szigorúbb büntetésben részesítik az attraktív csalókat, mint a nem attraktív csalókat (WILSON és ECKEL, 2006). Ezzel párhuzamosan azt várjuk, hogy a nem attraktív együttműködőknek magasabb jutalmat osztanak ki a kísérleti személyek, mint az attraktív együttműködőknek.

\section{Második hipotézis}

A korábbi kutatásokkal összhangban azt feltételezzük, hogy a beavatkozások mértékét a játékosok által keltett érzelmek mediálják (FEHR és FISCHBACHER, 2004b; DE KWAADSTENIET és mtsai, 2013). A sztereotípia-inkonzisztens helyzetek várhatóan intenzívebb érzelmeket váltanak ki a résztvevőkből, mint a sztereotípia-konzisztens helyzetek.

\section{MÓDSZER}

\section{Minta}

A vizsgálatban a Pécsi Tudományegyetem 115 bölcsész-, valamint természettudományi karán tanuló hallgató vett részt, ebből 57 férfi ( $M$ életkor $=21,3$ év; $S D=$ 2,13 ) és 58 nő ( $M$ életkor $=21,1$ év; $S D=2,11$ ). A kísérletben való részvétel önkéntes alapon és teljes mértékben anonim módon történt. A játékban való teljesítményük alapján a kísérleti személyek 1000-5000Ft közötti kifizetésben részesültek.

\section{Az ingeranyag bemérése}

A kutatás ingeranyagát képező 16 arcképet egy elővizsgálat keretében összesen 89, semleges arckifejezésủ női és férfi portré közül választottuk ki, melyek egy korábbi vizsgálat adatbázisából származtak (lásd MEskó, 2007). A fotók kiválasztásakor fontos szempont volt, hogy a kísérlet leendő résztvevői ne ismerjék fel az arcokat. A Pécsi Pszichológia Intézet 48 BA-szakos hallgatója (7 férfi és 41 nő) 7 fokú Likert-skálán ítélték meg az arcokat az attraktivitás, valamint a megbizhatóság dimenziók mentén. A portrékra kapott átlagértékek alapján (felső, ill. alsó 25\%) 8 férfi ( 4 attraktív és 4 nem attraktív), valamint 8 női (4 attraktív és 4 nem attraktív) fényképet választottunk ki.

Ezt követően a vonzónak ítélt férfi és női arcokat (4-4 db) a PsychoMorph nevű program segítségével 50-10-10 arányban (forma-szín-textúra) összemorfoltuk a 
Pszichológia Intézetben korábban végzett kutatások alkalmával létrehozott attraktív, maszkulin férfi átlagarccal, illetve attraktív, feminin női átlagarccal (MESKó, 2007; Tiddeman, Stirrat és Perrett, 2005). Ily módon ezek az arcok még vonzóbbakká váltak, ugyanakkor továbbra is élethűek maradtak (2. ábra). A nem attraktív arcokat nem manipuláltuk.

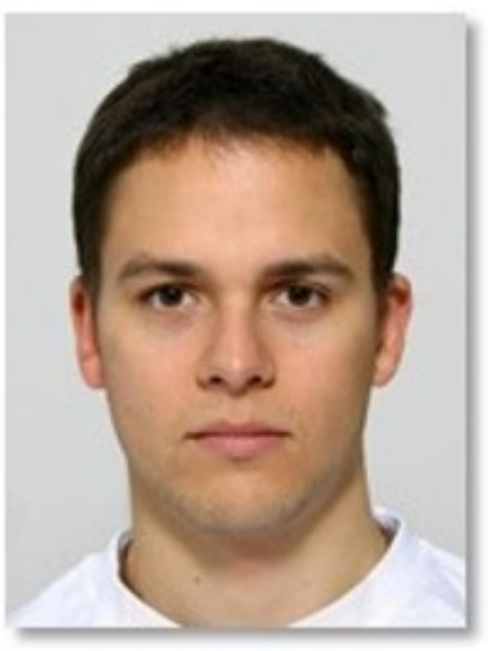

Attraktiv férfi

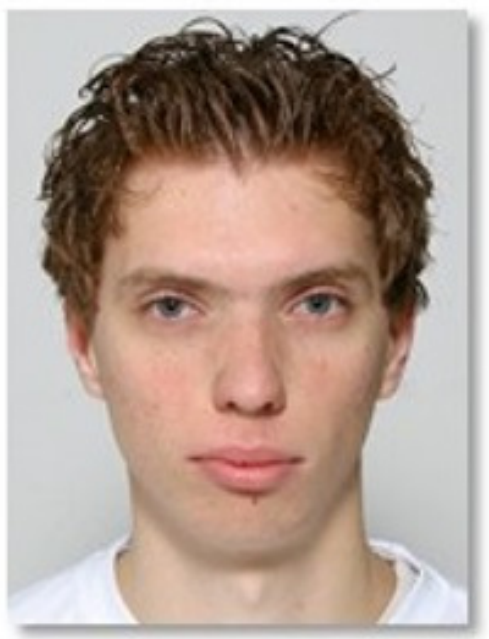

Nem attraktiv férfi

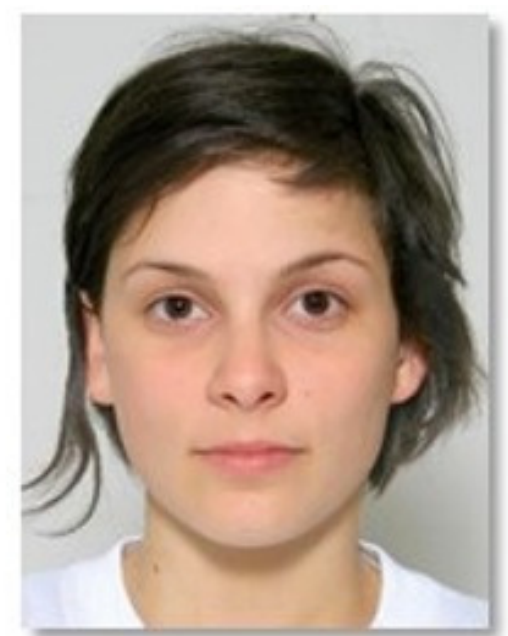

Attraktiv nő

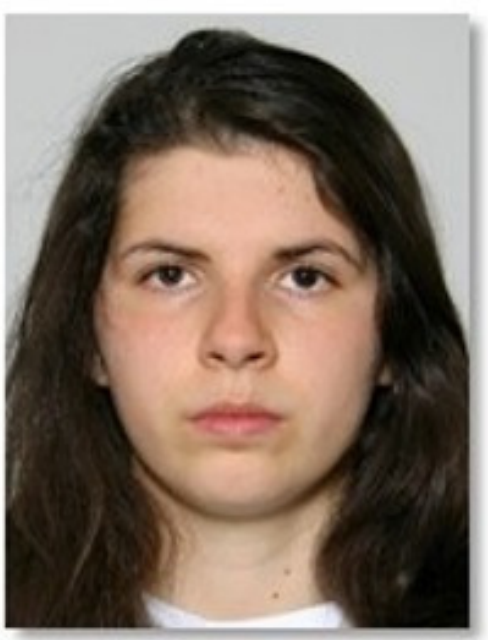

Nem attraktiv nö

2. ábra. Minta a vizsgálatban szereplő attraktív és nem attraktív férfi és női arcokról 
Az így létrejött ingeranyagot a fentebb már ismertetett módon ismét megítéltettük pécsi egyetemisták egy másik csoportjával (7 férfi és 42 nő). Az adatokat összetartozó mintás t-próbával elemezve bebizonyosodott, hogy a vonzó arcok mind attraktivitásukban, mind megbízhatóságukban szignifikánsan magasabb átlagértékekkel rendelkeztek, mint a kevésbé vonzó arcok (lásd 1. táblázat). A fényképekre adott attraktivitás-, illetve megbízhatóságítéletek között magas, szignifikáns korrelációt mértünk (Pearson $r=0,656 ; p<0,001$ ).

1. táblázat. A vizsgálatba beválogatott attraktív, valamint kevésbé attraktív arcok vonzósága, illetve megbízhatósága

\begin{tabular}{|c|c|c|c|c|}
\hline \multicolumn{2}{|c|}{ Összehasonlított változók } & Átlag & Szórás & Tesztstatisztika \\
\hline Attraktív arcok & \multirow{2}{*}{ vonzósága } & 4,31 & 0,66 & \multirow{2}{*}{$(48)=-26,76$} \\
\cline { 3 - 4 } & 1,87 & 0,53 & $p<0,001$ \\
\hline Kevésbé attraktív arcok & \multirow{2}{*}{ megbízhatósága } & 4,33 & 0,71 & \multirow{2}{*}{$(48)=8,17$} \\
\cline { 3 - 4 } & 3,37 & 0,76 & $p<0,001$ \\
\hline Kevésbé attraktraktív arcok & & \multicolumn{3}{|c}{} \\
\hline
\end{tabular}

A harmadik személyü büntetö-jutalmazó játék (TPRG)

A kutatásban használt kísérleti játékprogramot a szerzők egyike, Palotai Róbert készítette. A harmadik személyü büntető játékkal (TPG) ellentétben a TPRG ge-

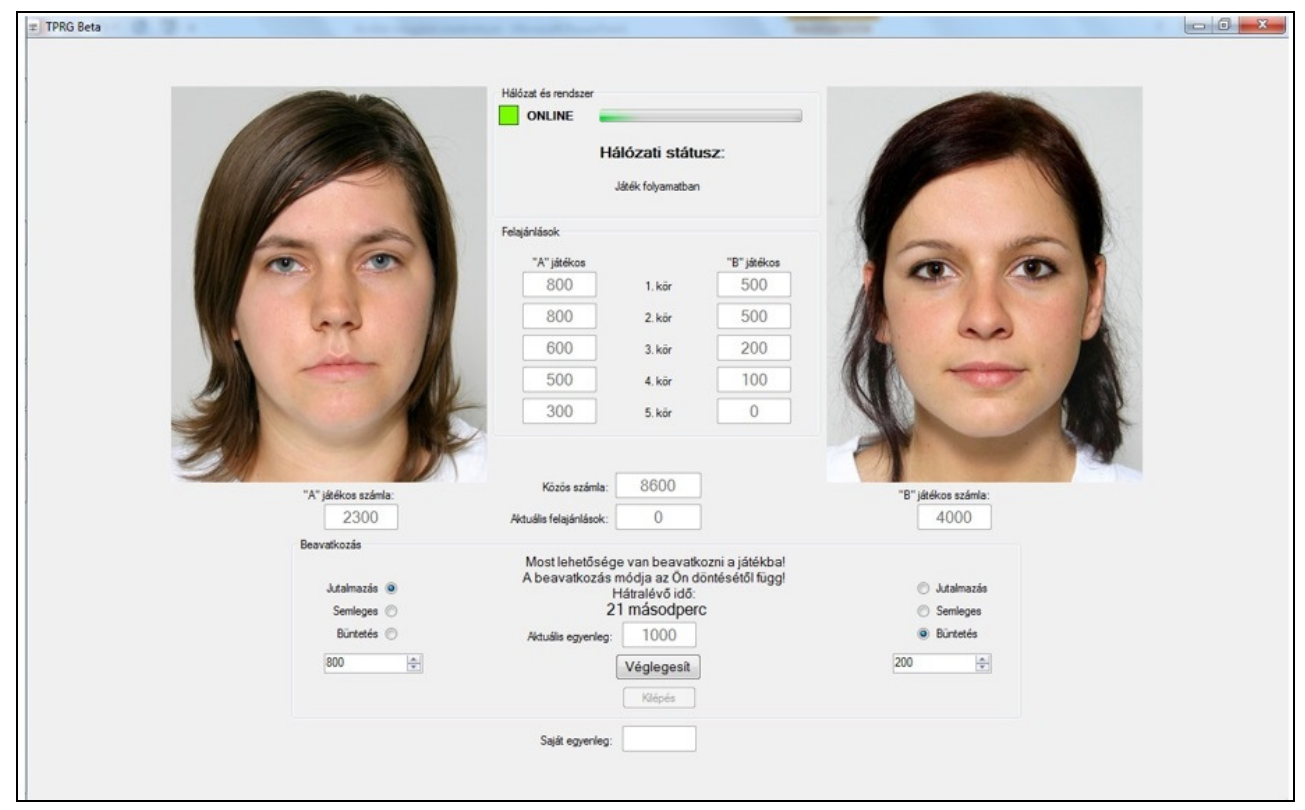

3. ábra. A vizsgálatban használt kísérleti játékprogram (TPRG) monitorképe 
rincét egy 5 körös mini közjavak játék (lásd BERECZKEI, 2009, 283) alkotja. A képernyő közepén minden fordulóban két fiktív, azonos nemü játékos felajánlásai jelennek meg (maximum $1000 \mathrm{Ft}$ ). A játékosok portréi a felajánlások két oldalán $320 \times 400$-as felbontásban láthatók (3. ábra).

A kísérleti személy feladata, hogy a játékosok felajánlásainak figyelemmel kísérése után büntesse vagy jutalmazza egyik vagy akár mindkét játékost; de dönthet úgy is, hogy egyáltalán nem avatkozik be a játékba (semleges pozíció). A megfigyelő saját számlájára minden fordulóban 2000 Ft kerül jóváírásra, amelynek terhére módosíthatja 'A', illetve 'B' játékos saját egyenlegét (a beavatkozás a közös számla összegét nem befolyásolja). A beavatkozás azonban költséges a kísérleti személy számára, hiszen a büntetésre és/vagy jutalmazásra szánt összeg levonódik a saját egyenlegéből, amely alapján a kísérlet végén kifizetésben részesül (2. táblázat). A résztvevőknek minden fordulóban 60 másodperc áll rendelkezésére döntésük meghozatalára.

2. táblázat. A játékosok kifizetése játékbeli teljesítményük alapján

\begin{tabular}{|c|c|}
\hline Játék végi egyenleg & Kifizetett összeg \\
\hline$>14400 \mathrm{Ft}(90 \%)$ & $5000 \mathrm{Ft}$ \\
\hline$>12800 \mathrm{Ft}(80 \%)$ & $4000 \mathrm{Ft}$ \\
\hline$>11200 \mathrm{Ft}(70 \%)$ & $3000 \mathrm{Ft}$ \\
\hline$>\quad 9600 \mathrm{Ft}(60 \%)$ & $2000 \mathrm{Ft}$ \\
\hline alatta & $1000 \mathrm{Ft}$ \\
\hline
\end{tabular}

A játék összesen 8 fordulóból állt. Ezek felében sztereotípia-konzisztens (attraktív együttműködő és nem attraktív csaló), másik felében sztereotípia-inkonzisztens (nem attraktív együttműködő és attraktív csaló) forgatókönyvekkel találkoztak a kísérleti személyek. A forgatókönyvek minden kísérleti személy esetén ugyanabban az előre randomizált sorrendben követték egymást. (A sorrend kialakításakor ügyeltünk rá, hogy ne kövesse egymást kettőnél több azonos (sztereotípia-konzisztens vagy -inkonzisztens) forgatókönyv. A férfi és női játékos párok felváltva követték egymást. Az oldalisági hatás kiküszöbölése érdekében a vonzó játékosok a fordulók felében a jobb, másik felében a bal oldalon jelentek meg.

A felajánlás-forgatókönyvek kialakításakor ügyeltünk arra, hogy a közjavak játék végére a sztereotípia-konzisztens és -inkonzisztens helyzetekben egyaránt azonos különbségek (1400-1800 Ft) alakuljanak ki a játékosok között. A csaló stratégiát képviselő játékosok a lehetséges maximális felajánlás 26-34\%-át, az együttműködők 60-68\%-át utalták át a közös számlára. 


\section{A kísérlet menete}

A kísérlet a Pécsi Tudományegyetem Pszichológia Intézetében zajlott. A résztvevők egyesével, egymástól elszeparáltan foglaltak helyet a számítógépek előtt. A vizsgálatra vonatkozó instrukciók elolvasása után a résztvevők egy demojátékban lehetőséget kaptak a büntetés és jutalmazás kipróbálására. Ezt követően kiosztottuk a válaszlapokat, melyeken a személyes adatok közül mindössze a résztvevők neme és életkora, valamint egy általuk választott azonosító (leggyakrabban EHA kód) szerepelt. Ez utóbbira a kísérlet végi kifizetések miatt volt szükség, melynek pontos összegét a játékban való teljesítmény határozta meg. Minél többet büntettek és/vagy jutalmaztak a résztvevők, annál kevesebb pénzzel távozhattak a kutatás végén (minimum $1000 \mathrm{Ft}$, maximum $5000 \mathrm{Ft}$ járt a részvételért). A kísérleti személyeket úgy tájékoztattuk, hogy egy országos, online vizsgálatban vesznek részt; a kutatás végén azonban felfedtük előttük a hipotéziseket, valamint a játék offline jellegét.

A résztvevők a TPRG-ben végzett beavatkozásaikat a válaszlapon is regisztrálták. Emellett arra kértük őket, hogy a fordulók közötti időben (kb. $10 \mathrm{mp}$ ) minden játékos esetén egy -3-tól (düh) +3-ig (elégedettség) terjedő skálán jelöljék a játékosok által bennük keltett érzelmeket.

\section{EREDMÉNYEK}

\section{Az attraktivitás hatása a beavatkozásokra}

A kísérleti személyek beavatkozásait 2 (Attraktivitás: attraktív, nem attraktív) $\times 2$ (Stratégia: együttműködő, csaló) összetartozó mintás varianciaanalízissel vizsgáltuk. Közbülső változóként a kísérleti személy neme (férfi, nő) szerepelt, melyben nem mutatkozott szignifikáns különbség $\{F(1,113)=0,26, p>0,05\}$. A fó hatások közül a stratégia $\left\{F(1,113)=229,15, p<0,001, \eta^{2}=0,67\right\}$, valamint az attraktivitás $\left\{F(1,113)=138,11, p<0,001, \eta^{2}=0,55\right\}$ is szignifikáns eredményt hozott. Ezek alapján megállapítható, hogy a résztvevők több jutalmat osztottak ki az együttműködő, valamint a nem attraktív játékosoknak (3. táblázat).

Szignifikáns interakciót kaptunk az attraktivitás és a stratégia tekintetében $F(1,113)=7,36, p<0,009, \eta^{2}=0,06$ (4. ábra). Ez alapján elmondható, hogy a

3. táblázat. A beavatkozások átlaga és szórása a játékosok stratégiája, valamint attraktivitása szerint

\begin{tabular}{|c|c|c|c|}
\hline & & Átlag & Szórás \\
\hline \multirow{2}{*}{ Stratégia } & Csaló & $-406,35$ & 600,27 \\
\hline & Együttmüködö & 412,59 & 547,49 \\
\hline \multirow{2}{*}{ Attraktivitás } & Attraktiv & $-289,17$ & 560,4 \\
\hline & Nem attraktív & 295,42 & 587,36 \\
\hline
\end{tabular}




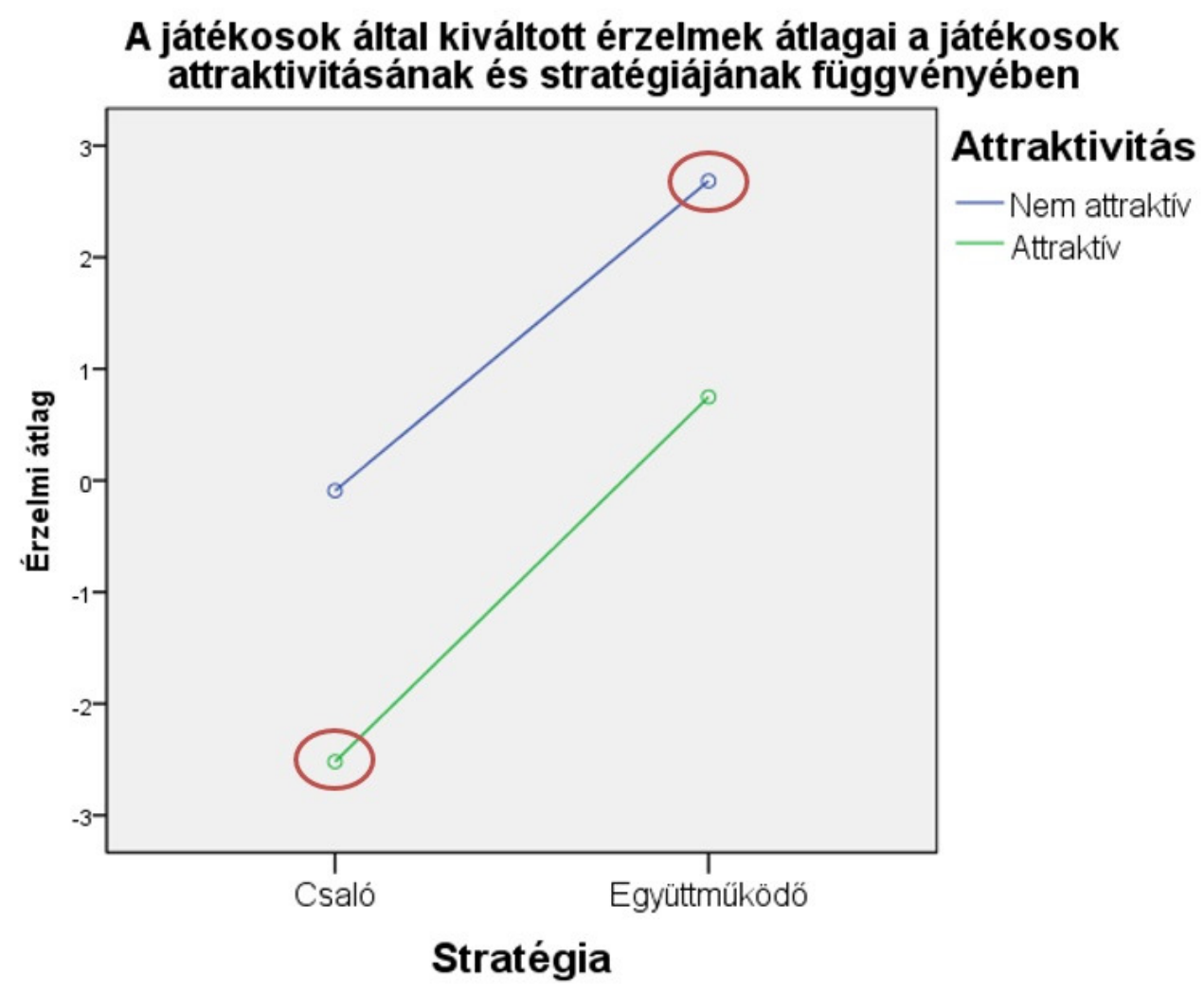

4. ábra. A kísérleti személyek beavatkozásainak átlaga a játékosok attraktivitásának és stratégiájának függvényében

sztereotípia-inkonzisztens helyzetekben a kísérleti személyek szigorúbb büntetéseket (attraktív csalók $M=-2,52 ; S D=2,2$ ) és magasabb jutalmakat (nem attraktív együttmüködők $M=2,68 ; S D=1,78$ ) osztottak ki, mint a sztereotípia-konzisztens helyzetekben (nem attraktív csalók $M=-0,09 ; S D=1,58$ és attraktív együttmüködők $M=0,75 ; S D=1,35)$ (4. táblázat).

4. táblázat. A kísérleti személyek beavatkozásainak átlaga és szórása a játékosok vonzerejének és stratégiájának függvényében

\begin{tabular}{|l|c|c|}
\hline \multirow{2}{*}{ A játékos vonzereje } & \multicolumn{2}{|c|}{ A játékos stratégiája } \\
\cline { 2 - 3 } & Együttmüködö & Csaló \\
\hline Attraktív & $162,61(457,47)$ & $-\mathbf{7 4 1 , 3 0}(663,33)$ \\
\hline Nem attraktív & $\mathbf{6 6 3 , 4 7}(637,51)$ & $-71,73(537,21)$ \\
\hline
\end{tabular}




\section{A játékosok által kiváltott érzelmek}

A játékosokra adott érzelmi válaszokat 2 (Attraktivitás: attraktív, nem attraktív) × 2 (Stratégia: együttműködő, csaló) összetartozó mintás varianciaanalízissel vizsgáltuk. Közbülső változóként a kísérleti személy neme (férfi, nő) szerepelt, amelyben nem mutatkozott szignifikáns különbség $\{F(1,113)=0,84, p>0,05\}$. A fö hatások közül mind a stratégia $\left\{F(1,113)=315,06, p<0,001, \eta^{2}=0,73\right\}$, mind az attraktivitás $\left\{F(1,113)=177,22, p<0,001, \eta^{2}=0,61\right\}$ szignifikáns eredményt hozott. Ezek alapján megállapítható, hogy a résztvevők pozitívabb érzelmeket éltek át az együttműködő, nem attraktív, illetve női játékosok iránt (5. táblázat).

5. táblázat. A játékosok által keltett érzelmek átlaga és szórása a játékosok stratégiája, valamint attraktivitása szerint

\begin{tabular}{|c|c|c|c|}
\hline & & Átlag & Szórás \\
\hline \multirow{2}{*}{ Stratégia } & Csaló & $-1,3$ & 1,89 \\
\hline & Együttmüködő & 1,71 & 1,57 \\
\hline \multirow{2}{*}{ Attraktivitás } & Attraktív & $-0,88$ & 1,77 \\
\hline & Nem attraktív & 1,29 & 1,68 \\
\hline
\end{tabular}

Szignifikáns interakciót kaptunk az attraktivitás és a stratégia tekintetében $F$ $(1,113)=10,48, p<0,003, \eta^{2}=0,08$ (5. ábra). Ez alapján elmondható, hogy a sztereotípia-inkonzisztens helyzetekben (attraktív csalók $M=-2,52 ; S D=2,2$ és nem attraktív együttműködők $M=2,68 ; S D=1,78)$ a kísérleti személyek intenzívebb érzelmeket éltek át, mint a sztereotípia-konzisztens helyzetekben (nem attraktív csalók $M=-0,09 ; S D=1,58$ és attraktív együttműködők $M=0,75 ; S D=1,35$ ) (6. táblázat).

6. táblázat. A játékosok által keltett érzelmek átlaga és szórása vonzerő és stratégia szerint

\begin{tabular}{|l|c|c|}
\hline \multirow{2}{*}{ A játékos vonzereje } & \multicolumn{2}{|c|}{ A játékos stratégiája } \\
\cline { 2 - 3 } & Együttmüködö & Csaló \\
\hline Attraktív & $0,75(1,35)$ & $\mathbf{- 2 , 5 2}(2,2)$ \\
\hline Nem attraktív & $\mathbf{2 , 6 8}(1,78)$ & $-0,09(1,58)$ \\
\hline
\end{tabular}

Az azonos nemű és stratégiájú, ám különböző vonzerővel bíró játékosokra adott érzelmi válaszokat összetartozó mintás $t$-próbával elemezve mind a férfi, mind a női kísérleti személyek esetében szignifikáns különbségeket kaptunk. A vonzóbb játékosok mindkét nem tagjaiban negatívabb érzelmeket váltottak ki (7. táblázat). 


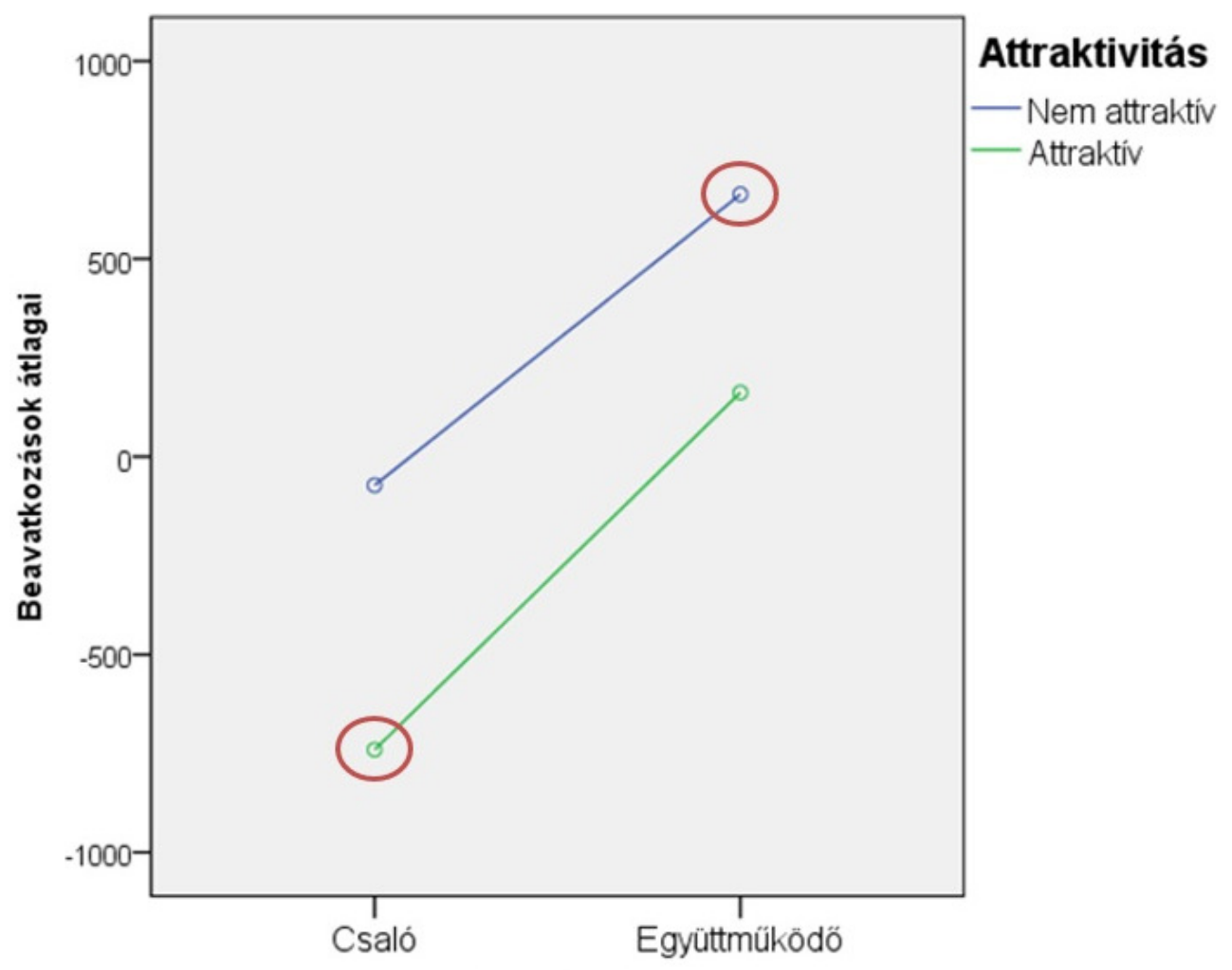

Stratégia

5. ábra. A játékosok által kiváltott érzelmek átlagai a játékosok attraktivitásának és stratégiájának függvényében

7. táblázat. A játékosok által kiváltott érzelmek átlagai és szórásuk a kísérleti személyek neme szerint

\begin{tabular}{|c|c|c|c|c|c|c|c|}
\hline \multirow{2}{*}{ Összehasonlított játékosok } & & \multicolumn{3}{|c|}{ Férfi kisérleti személyek } & \multicolumn{3}{|c|}{ Nöi kisérleti személyek } \\
\hline & & Átlag & Szórás & Tesztstatisztika & Átlag & Szórás & Tesztstatisztika \\
\hline xödő & \multirow{2}{*}{$\ddot{z}$} & 0,56 & 1,35 & \multirow[b]{2}{*}{$\begin{array}{c}t(56)=-7,13 \\
p<0,001\end{array}$} & 0,64 & 1,3 & \multirow[b]{2}{*}{$\begin{array}{c}t(56)=-7,86 ; \\
p<0,001\end{array}$} \\
\hline $\begin{array}{l}\text { Nem } \\
\text { núk }\end{array}$ & & 2,49 & 1,86 & & 2,33 & 1,62 & \\
\hline Attr & \multirow[t]{2}{*}{0} & $-2,14$ & 1,95 & \multirow{2}{*}{$\begin{array}{c}t(56)=-5,66 \\
p<0,001\end{array}$} & $-2,52$ & 2,31 & \multirow{2}{*}{$\begin{array}{c}t(56)=-8,91 ; \\
p<0,001\end{array}$} \\
\hline Nen & & $-0,11$ & 1,6 & & $-0,14$ & 1,17 & \\
\hline Attr & \multirow{4}{*}{$\begin{array}{l}: 0 \\
=\end{array}$} & 1,05 & 1,6 & \multirow{2}{*}{$\begin{array}{c}t(56)=-5,76 \\
p<0,001\end{array}$} & 0,74 & 1,14 & \multirow{2}{*}{$\begin{array}{c}t(56)=-8,67 ; \\
p<0,001\end{array}$} \\
\hline $\begin{array}{l}\text { Nem } \\
\text { núki }\end{array}$ & & 3 , & 1 , & & 2 , & 1 , & \\
\hline ttral & & $-2,54$ & 2,37 & \multirow{2}{*}{$\begin{array}{c}t(56)=-7,14 \\
p<0,001\end{array}$} & $-2,88$ & 2,16 & \multirow{2}{*}{$\begin{array}{c}t(56)=-8,68 ; \\
p<0,001\end{array}$} \\
\hline & & & 1,8 & & 0,02 & 1,71 & \\
\hline
\end{tabular}




\section{MEGVITATÁS}

A kísérleti személyek által kiosztott büntetések és jutalmazások mértéke magas korrelációt mutatott a játékosok által keltett érzelmekkel (Pearson $r=0,61 ; p<$ 0,001). Bár a korrelációból nem következtethetünk oksági viszonyra, a szakirodalomra támaszkodva joggal feltételezhetjük, hogy a beavatkozások mértékét az átélt érzelmek mediálták (DE KWAADSTENIET, RIJKHOFF és VAN DiJK, 2013; FeHR és FISCHBACHER, 2004b).

Az előzetes feltételezéseknek megfelelően a sztereotípia-inkonzisztens helyzetek intenzívebb érzelmeket váltottak ki a résztvevőkből, illetve magasabb büntetések és jutalmazások kiszabásához vezettek. Ez nem meglepő, hiszen az együttműködés társas normáinak megszegését kísérő intenzív negatív érzelmekről már több kutatás is beszámolt (DE KWAADSTENIET, RIJKHOFF és VAN DiJK, 2013; FeHR és FiSCHBACHER, 2004b). Kísérletünkben igazoltuk, hogy az attraktívabb személyek normaszegését intenzívebb negatív érzelmek és magasabb büntetések kísérik, mint a kevésbé attraktív csalókét. Ennek oka feltehetően az attraktívabb személyekkel szembeni magasabb elvárásokban keresendő (WILSON és ECKEL, 2006).

Elképzelhető ugyanakkor az is, hogy a vonzóbb személyekkel szembeni intenzívebb negatív érzelmeket az intraszexuális (nemen belüli) rivalizáció magyarázza. AGTHE, SPÖRRLE és MANER (2010) kutatásából tudjuk, hogy a kísérleti személyekkel azonos nemű, vonzó külsejű személyek nem csupán párválasztási kontextusban, hanem azon kívül (például a munka világában) is hátrányos megkülönböztetésben részesülnek a riválisok által. Ennek a feltevésnek az ellenőrzésére a különböző attraktivitású, de azonos nemü és stratégiájú játékosok által kiváltott érzelmi válaszokat nemi bontásban összetartozó mintás t-próbával elemeztük. Az eredmények tanúsága szerint a játékosok nemétől függetlenül mind a női, mind a férfi kísérleti személyek intenzívebb érzelmeket éltek át a sztereotípia-inkonzisztens helyzetek megfigyelésekor (7. táblázat). Ez alapján tehát elvethetjük az intraszexuális rivalizáció gondolatát, hiszen a kísérleti személyek nem csupán a velük azonos nemü vonzó játékosokkal szemben éltek át intenzívebb érzelmeket, hanem a másik nem tagjaival szemben is.

A normaszegés által keltett negatív érzelmek mellett - DE KWAADSTENIET, RIJKHOFF és VAN DIJK (2013) eredményeihez hasonlóan - az együttműködők iránt érzett pozitív érzelmekről számoltak be kísérleti személyeink. Eredményeinkből kiderült, hogy a sztereotípia-inkonzisztens helyzetekben, más szóval a nem attraktív együttmüködők játékát látva, erősebb megelégedést éltek át a résztvevők és magasabb jutalmakat osztottak ki. Ez szintén magyarázható az előzetes elvárásokkal, mely alapján a nem attraktív személyeket kevésbé együttműködőnek gondolhatták a kísérleti személyek (GRIFFIN és LANGLOIS, 2006). Ennek következtében a játékosok kooperatív viselkedése pozitív csalódást kelthetett a megfigyelőkben. A kevésbé attraktív játékosok által keltett pozitívabb érzelmeket magyarázhatja továbbá az irántuk érzett együttérzés is, amely ún. „vigaszdíj” odaítélésére ösztönözhette a résztvevőket (CONDON és DESTENO, 2011).

További vizsgálatok szükségesek annak eldöntésére, hogy a két csoport (attraktív és nem attraktív) közötti különbségek kizárólag az attraktív személyekkel szem- 
beni magasabb elvárások vagy a kevésbé attraktív személyek iránt érzett „részvét” miatt jöttek-e létre. Kérdés továbbá, hogy hogyan befolyásolja a játékosok neme a beavatkozások mértékét. A jövőben a kísérleti személyek beavatkozásainak hátterében meghúzódó motívumokat narratív tartalomelemzés segítségével kívánjuk feltérképezni.

\section{IRODALOM}

Agthe, M., Spörrle, M., \& Maner, J. K. (2010). Don't hate me because I'm beautiful: Antiattractiveness bias in organizational evaluation and decision making. Journal of Experimental Social Psychology, 46, 1151-1154.

Andreoni, J., \& Petrie, R. (2008). Beauty, gender and stereotypes: Evidence from laboratory experiments. Journal of Economic Psychology, 29, 73-93.

BereczKei T. (2009). Az erény természete: Önzetlenség, együttmüködés, nagylelküség. Budapest: Typotex.

BERECZKEI T. (2010). Az arc vonzereje 1. Evolúciós és kulturális hatások. In RÉvész Gy. (szerk.), Az emberi arc: Tanulmányok a pszichológia, az orvostudomány, a mesterséges intelligencia és a képzömüvészet területeiről (89-117). Pécs: Pro Pannonia Kiadói Alapítvány.

Condon, P., \& DeSteno, D. (2011). Compassion for one reduces punishment for another. Journal of Experimental Social Psychology, 47, 698-701.

Darwin, CH. (1859). On The Origin of Species by Means of Natural Selection, or The Preservation of Favoured Races In The Struggle for Life. London: John Murray. Letöltve 2012. március 2-án, http://darwin-online.org.uk/contents.html

Darwin, CH. (1871). The Descent of Man, and Selection in Relation with Sex (Vol. 1). London: John Murray. Letöltve 2012. február 20-án, http://darwin-online.org.uk/contents.html

De KwaAdsteniet, E. W., Rijkhoff, S. A. M., \& van Dijk, E. (2013). Equality as a benchmark for third-party punishment and reward: The moderating role of uncertainty in social dilemmas. Organizational Behavior and Human Decision Processes, 120, 251-259.

Dion, K., Berscheid, E., \& WALSTER, E. (1972). What is beautiful is good. Journal of Personality and Social Psychology, 24(3), 285-290.

Dijksterhuis, A., \& VAn Knippenberg, A. (1995). Memory for stereotype-consistent and stereotype-inconsistent information as a function of processing pace. Journal of Experimental Social Psychology, 25, 689-693.

FEHR, E., \& FischBACHER, U. (2003). The nature of human altruism. Nature, 425, 785-791.

Fehr, E., \& Fischbacher, U. (2004a). Social norms and human cooperation. Trends in Cognitive Science, 8(4), 185-190.

FEHr, E., \& FischBACHER, U. (2004b). Third-party punishment and social norms. Evolution and Behavior, 25, 63-87.

Fink, B., Neave, N., Manning, J. T., \& Grammer, K. (2006). Facial symmetry and judgements of attractiveness, health and personality. Personality and Individual Differences, 41, 491-499.

Gintis, H., Bowles, S., BOyd, R., \& FEHR, E. (2003). Explaining altruistic behavior in humans. Evolution and Human Behavior, 24, 153-172. 
Grammer, K., Fink, B., Møller, A. P., \& Thornhill, R. (2003). Darwinian aesthetics: Sexual selection and the biology of beauty. Biological Reviews, 78, 385-407.

Griffin, A. M., \& LANGlois, J. H. (2006). Stereotype directionality and attractiveness stereotyping: Is beauty good or is ugly bad? Social Cognition, 24(2), 187-206.

Heider, J. D., Scherer, C. R., Skowronski, J. J., Wood, S. E., Edlund, J. E., \& HartnetT, J. L. (2007). Trait expectancies and stereotype expectancies have the same effect on person memory. Journal of Experimental Social Psychology, 43, 265-272.

KiYOnari, T., TANida, SH., \& Yamagishi, T. (2000). Social exchange and reciprocity: Confusion or a heuristic? Evolution and Human Behavior, 21, 411-427.

Little, A. C., Jones, B. C., \& DeBruine, L. M. (2011). Facial attractiveness: Evolutionary based research. Philosophical Transactions of the Royal Society B, 366, 1638-1659.

MESkó N. (2007). A nói arc darwini esztétikája: átlagosság, neoténia, hormonális markerek és hajuiselet szerepe a nöi arc fenotípusos minőségének megitélésében. Nem publikált $\mathrm{PhD}$ disszertáció. Pécs: Pécsi Tudományegyetem.

Mulford, M., Orbell, J., Shatto, C., \& Stockard, J. (1998). Physical attractiveness, opportunity, and success in everyday exchange. American Journal of Sociology, 103(6), $1565-1592$.

Payne, B. K., Jacoby, L. L., \& Lambert, A. J. (2004). Memory monitoring and the control of stereotype distortion. Journal of Experimental Social Psychology, 40, 52-64.

Stangor, Ch., \& Ruble, D. N. (1989). Strength of Expectancies and Memory for Social Information: What We Remember Depends on How Much We Know. Experimental Social Psychology, 25, 18-35.

Tiddeman, B. P., Stirrat, M. R., \& Perrett, D. I. (2005). Towards realism in facial image transformation: Results of a wavelet MRF method. Computer Graphics Forum, 24, 449-456.

Trivers, R. L. (1971). The evolution of reciprocal altruism. The Quarterly Review of Biology, $46(1), 35-57$.

Thorndyke, P. W., \& HAYES-Roth, B. (1979). The use of schemata in the acquisition and transfer of knowledge. Cognitive Psychology, 11, 82-106.

West, S. A., Mouden, C. El, \& Gardner, A. (2011). Sixteen common misconceptions about the evolution of cooperation in humans. Evolution and Human Behavior, 32, 231-262.

Wilson, R. K., \& ECKEL, C. C. (2006). Judging a book by its cover: Beauty and expectations in the trust game. Political Research Quarterly, 59(2), 189-202.

\title{
"WHO'S BEAUTIFUL, WHO'S GOOD?" THE EFFECT OF ATTRACTIVENESS ON THIRD-PARTY PUNISHMENT AND REWARD
}

\author{
PUTZ, ÁDÁM - PALOTAI, RÓBERT - BERECZKEI, TAMÁS
}

According to DION, BERSCHEID and WALSTER (1972) people tend to assume that highly attractive individuals possess more socially desirable personality traits (e.g. "altruistic") than those of lesser attractiveness. In a game involving trust and reciprocity WILSON and ECKEL (2006) found that attrac- 
tive trustees were viewed as more trustworthy; should they fail to reciprocate however, participants inflict larger punishments on them than on less attractive cheaters ("beauty penalty").

In our study we intended to analyse how attractiveness affects the social norm enforcement in a third-party punishing and rewarding context. The Third-party Punishment and Reward Game (TPRG) consisted out of two steps. First the participants had to observe a short "Public Goods Game" between two fictitious individuals, and then they had the opportunity to punish and/or to reward either just one or both players. Interfering in the game was costly for the participants. Among the eight rounds of the game there were stereotype consistent (attractive co-operators with unattractive freeriders) and stereotype inconsistent (attractive free-riders with unattractive co-operators) scenarios.

All of our 115 participants (58 females and 57 males) were volunteer undergraduate university students, aged between 18 and 31 years (mean $=21.2 ; S D=2.12$ ). In line with WILSON and ECKEL (2006) we found that attractive free-riders were punished more severely than unattractive ones. Additionally participants rewarded unattractive co-operators more than those of higher attractiveness. Thus we can conclude that stereotype inconsistent scenarios evoke more extreme interventions than stereotype consistent scenarios did.

Key words: social norm enforcement, third-party punishment and reward, strong reciprocity, attractiveness, beauty-stereotypes, stereotype-consistency/inconsistency, TPRG 